\section{Dr. F. U. Klaehn}

Dr. Friedrich U. KLAEHN, associate professor of sylviculture at the State University College of Forestry at Syracuse University, died suddenly of a heart attack in Crouse-Irving Hospital on October 21, aged forty-six.

An international authority on forest tree genetics and efforts to improve forest tree species, Dr. Klaehn was born and educated in Germany. He was a native of EssenSteele, Ruhr, where he was born on October 27, 1915. He was a holder of forestry and Ph.D. degrees from the University of Göttingen, Göttingen, West Germany. His two degrees were earned in 1949 and 1950 , respectively. He went to Syracuse on his appointment to the College of Forestry faculty on October 1, 1955. He was a member of the faculty and research staff of the Depart. ment of Silviculture.

He is survived by his widow, the former Miss Ingrid $\mathrm{H}$. Schrader, two children and his parents.

\section{Dr. Carl R. Eklund}

Dr. Carl R. EkLund, noted Antarctic explorer and chief of Polar and Arctic research for the United States Army, died suddenly on November 4, 1962, in Philadelphia, where he had been lecturing at the Museum of Natural Science. He was fifty-three years old.

A native of Tomahawk, Wisconsin, he was given the key to the city last year as an "honoured son", during its Diamond Jubilee celebration. Dr. Eklund graduated from Carleton College in Minnesota, in 1932, and began his twenty-nine years of Government service as a forestry foreman in Virginia's Shenandoah National Park. In 1936, he transferred to the Fish and Wildlife Service as a research biologist and ornithologist, serving in various locations, including Michigan, Oregon, Illinois, and Washington. He received his master's degree from Oregon State College in 1936. During the Second World War, he served as a major in the Arctic section of the Arctic Degert Tropie Information Center of the Army Air Forces and was assigned to missions in Greenland and Canada. His last post with the Fish and Wildlife Service before his resignation in 1957 was as assistant regional director in Atlanta, Georgia. During the International Geophysical year, 1957-58, Eklund served for eighteen months as scientific leader at Wilkes Station, Antaretica. His thesis for his Ph.D. degree at the University of Maryland in 1959 was based on his work at Wilkes, where he solved the mystery concerning the penguin egg's incubation temperature by 'borrowing' an egg from the Adelie penguin, implanting a tiny temperature sensor and radio transmitter, and replacing the egg in the nest. He then monitored its average temperature, which he found to be 92.7 degrees, only $11 \cdot 1$ degrees lower than the body temperature of the bird which was incubating them, despite the surround. ing sub-zero temperatures. In 1958 , on his return from the Antarctic, he was appointed chief of the Polar and Arctic Branch of the Army Research Office.

Dr. Eklund made his first trip to the South Polar continent during 1939-41 as a member of the late RearAdmiral Richard E. Byrd's expedition, during which he and Finn Ronne made one of history's major Antaretic treks. They travelled 1,264 miles by dog-sled in 84 days, charting and mapping more than 350 miles of the Antarctic coast, and discovered a group of islands in King Georgo VI Sound, which has since been named the Eklund Islands. $\mathrm{He}$ and Ronne also determined that Alexander 1 Land is an island, linked to the mainland only by floating ice in a trough more than three times the length of Long Island Sound.

Dr. Eklund received international recognition for his work as an explorer and scientist. Recently he had returned from Paris, where he was an official representative of the Committee on Polar Research of the United States National Academy of Sciences. He was a member of the Explorers Club and was founder and first president of the Antaretican Society in Washington, D.C.

Dr. Eklund will be missed by his many friends and colleagues. He was one of the rare men who had no enemies; he had a great sense of humour and a kind attitude to his fellow man which made him a valued companion.

He is survived by his widow, Harriet, and two daughters, Linda and Signe.

KaARe RODAHL

\section{Mr. N. M. H. Lightfoot}

Nicholas MoRPETH Hutchinson LightFooT, principal of the Chelsea College of Science and Technology, died on November 20 at the age of sixty. Lightfoot was educated at Jarrow Grammar School, Co. Durham, proceeding from there by scholarship to Jesus College, Cambridge, to read mathematics. During 1929-43 he served on the mathematics staff of the Heriot-Watt College, Edinburgh, first as lecturer and later as head of the Department. In 1943 he was appointed principal of the South-East Essex Technical College, Dagenham. He moved to Chelsea in 1950 , where he was principal until his death.

At the beginning of his career he published papers on the mathematical theory of cooling steel, but later became primarily a teacher and then administrator.

During his long service as principal, first at Dagenham and later at Chelsea, he played an active part in matters concerning technical education and was elected president of the Association of Principals of Technical Institutions in 1955-56. He also served on the National Council for Technological Awards, the Parliamentary and Scientific Committee and the Regional Advisory Council.

His period as principal at Chelsea was marked by rapid developments in the College as the result of the change of status to a College of Advanced Technology, by which the old Chelsea Polytechnic became the Chelsea College of Science and Technology. This change required important decisions as to the proper direction for the future of the College. Up to the time of designation as a college of advanced technology, the College had been providing courses mainly for internal degrees of the University of London in science and pharmacy. Unlike all the other colleges of advanced technology, there was no school of engineering. It was chiefly as a result of Lightfoot's deliberations that the College continued to provide courses such as were traditional, but to develop research and postgraduate courses of an applied nature. Because of this decision, Chelsea College has a higher percentage of postgraduate work than any other college of advanced technology despite great limitations of space. In this way, Lightfoot felt that the College would play a proper part in its new capacity.

As a man, Lightfoot was quiet and retiring in his behaviour. In all that he did he was extremely conscientious with a sharp eye for detail. He came to a decision only after mature thought, but once he had made up his mind he went ahead with determination. $\mathrm{He}$ was a man of the highest integrity and because of this his staff knew that he could always be trusted. Likewise, he never interfered with his heads of Departments, leaving it to them, as experts in their own particular fields, to run their departments in their own way. In his unobtrusive way he has left his mark on the College and he will be sadly missed.

Lightfoot's death came tragically soon after that of his wife in December 1961, and our sympathies go out to his only daughter in losing both her parents in so short a time.

C. C. Hentschel

\section{Mr. E. C. Stubbens}

Ernest Charles Stubbens, who died on Novernber 16 at his home in Shelford, was born in Cambridge on May 3, 1899. He began a lifetime devoted to the scientific 